\title{
PENINGKATAN KEMAMPUAN BERPIKIR KRITIS DAN LOGIS MATEMATIK SISWA SMK NEGERI 1 SIGLI MELALUI MODEL KOOPERATIF TIPE STAD BERBANTUAN MAPLE
}

\author{
Maryanti $^{1}$, Laila Qadriah ${ }^{2}$ \\ ${ }^{1,2}$ Program Studi Teknik Informatika, Fakultas Teknik Informatika \\ Universitas Jabal Ghafur
}

\begin{abstract}
ABSTRAK
Kemampuan berpikir kritis matematik dan berpikir logis matematik sangat penting dalam pembelajaran matematika, sebagimana yang telah diuraikan dalam buku kurikulum 2013 yang saat ini sedang berlangsung. Namun kemampuan ini sering terabaikan dalam pembelajaran matematika yang masih menganut paradigma lama yaitu pembelajaran yang kurang melibatkan siswa dalam berpikir aktif sehingga siswa tidak terbiasa memberdayakan fungsi kognitifnya dalam berpikir. Salah satu upaya untuk mengembangkan siswa berpikir aktif khususnya pada materi eksponen dibutuhkan suatu strategi pembelajaran yang inovatif yaitu model pembelajaran STAD berbantuan Maple. Penelitian ini bertujuan untuk mengetahui peningkatan kemampuan berpikir kritis dan logis matematik siswa yang mendapat pembelajaran matematika melalui model kooperatif tipe STAD berbantuan Maple. Penelitian ini menggunakan metode eksperimen dengan desain penelitian pretest-posttest control grup desain. populasi adalah seluruh siswa kelas X SMK Negeri 1 Sigli dengan mengambil dua kelas sebagai sampel yaitu kelas eksperimen dan kelas kontrol, melalui teknik random sampling dari tiga kelas paralel yang tersedia. Pengumpulan data dilakukan dengan menggunakan instrumen tes yang meliputi tes kemampuan berpikir kritis dan logis. Untuk melihat adanya perbedaan kemampuan siswa antara kelompok Student Team Achievement Division dengan kelompok konvensional digunakan uji-t pada taraf signifikansi 0,05 setelah prasyarat pengujian terpenuhi. Berdasarkan hasil penelitian, diketahui bahwa: 1) Peningkatan kemampuan berpikir kritis matematik siswa yang mendapat pembelajaran matematika melalui model kooperatif tipe STAD berbantuan Maple lebih baik dari pada siswa yang mendapat pembelajaran konvensional, ditinjau dari: (a) keseluruhan, dan (b) subkelompok (tinggi, sedang, rendah); 2) Peningkatan kemampuan berpikir logis matematik siswa yang mendapat pembelajaran matematika melalui model kooperatif tipe STAD berbantuan Maple lebih baik dari pada siswa yang mendapat pembelajaran konvensional, ditinjau dari: (a) keseluruhan, dan (b) subkelompok (tinggi, sedang, rendah).
\end{abstract}

Kata Kunci: STAD, Berpikir Kritis, Berpikir Logis, Maple.

\section{PENDAHULUAN}

Matematika memegang peranan penting dalam perkembangan ilmu pengetahuan dan teknologi, baik sebagai alat bantu dalam penerapan ilmu lain maupun dalam pengembangan matematika itu sendiri. Dalam perkembangannya, konsep matematika banyak diperlukan untuk membantu menyelesaikan masalah dalam kehidupan sehari-hari, seperti halnya untuk membantu manusia dalam memahami dan mengatasi permasalahan sosial, ekonomi, IPA dan Teknologi Informatika.

Matematika sebagai salah satu disiplin ilmu yang diajarkan pada setiap jenjang pendidikan sekolah, diharapkan dapat memberikan sumbangan dalam rangka pengembangan kemampuan berpikir kritis, sistematis, logis, kreatif, dan bekerja sama secara efektif. Sikap dan cara berpikir seperti ini dapat dikembangkan melalui pembelajaran matematika, karena 
matematika memiliki struktur dan keterkaitan yang kuat dan jelas antara konsepnya, sehingga memungkinkan siapapun yang mempelajarinya terampil dalam berpikir secara rasional dan siap menghadapi permasalahan dalam kehidupan sehari-hari (Setiawan, 2011).

Upaya untuk meningkatkan kemampuan matematik siswa tidak hanya berguna untuk memperoleh hasil belajar yang tinggi, lebih dari itu sebagai bekal bagi siswa untuk menjalani kehidupan bermasyarakat, dan inilah konsep kehidupan matematika dan matematika untuk kehidupan.

Sehubungan dengan kemampuan matematika yang merupakan ilmu terstruktur dan sistematis, serta mengembangkan sikap berpikir kritis, objektif, dan terbuka, maka mengembangkan kemampuan berpikir kritis dan berpikir logis dalam pembelajaran matematika sangatlah penting digunakan dalam proses belajar mengajar.

Kemampuan berpikir kritis merupakan bagian dari kemampuan berpikir matematik yang perlu dimiliki oleh setiap siswa dalam menghadapi berbagai permasalahan. Pentingnya mengembangkan kemampuan berpikir kritis juga didasarkan pada visi pendidikan matematika yang mempunyai dua arah pengembangan yang dikemukakan oleh Sumarno (2002), yaitu memenuhi kebutuhan masa kini dan masa yang akan datang. Visi pertama untuk kebutuhan masa kini, pembelajaran matematika mengarah pada konsep-konsep yang diperlukan untuk menyelesaikan masalah matematika dan ilmu pengetahuan lainnya. Visi kedua untuk kebutuhan masa yang akan datang atau mengarah ke masa depan, mempunyai arti lebih luas yaitu pembelajaran matematika memberikan kemampuan nalar yang logis, sistematis, kritis, serta berpikir objektif dan terbuka yang sangat diperlukan dalam kehidupan sehari-hari serta untuk menghadapi masa depan yang selalu berubah.
Berdasarkan beberapa pendapat tersebut, dapat dikatakan berpikir kritis merupakan suatu proses berpikir yang bertujuan untuk membuat keputusankeputusan yang rasional yang diyakini kebenarannya dan mengoreksi secara kritis suatu informasi baru atau suatu permasalahan. Orang yang berpikir kritis adalah seseorang yang berpikir sendiri dan bertanggung jawab atas keputusankeputusan yang diambilnya dalam kehidupan.

Seyogyanya usaha untuk meningkatkan kemampuan berpikir kritis dan logis melalui pembelajaran matematika yang bermakna, telah dijabarkan dalam buku Matematika kurikulum 2013 untuk Pendidikan Menengah bertujuan memberi pengalaman konkret-abstrak kepada peserta didik. Pembelajaran matematika melalui buku ini akan membentuk kemampuan peserta didik dalam menyajikan gagasan dan pengetahuan konkret secara abstrak, menyelesaikan permasalahan abstrak yang terkait, dan berlatih berfikir rasional, kritis dan kreatif. Sebagai bagian dari Kurikulum 2013 yang menekankan pentingnya keseimbangan kompetensi sikap, pengetahuan dan keterampilan, kemampuan matematika yang dituntut dibentuk melalui pembelajaran berkelanjutan: dimulai dengan meningkatkan pengetahuan tentang metodemetode matematika, dilanjutkan dengan keterampilan menyajikan suatu permasalahan secara matematis dan menyelesaikannya, dan bermuara pada pembentukan sikap jujur, kritis, kreatif, teliti, dan taat aturan.

Selanjutnya Fisher (Agustine, 2009) menekankan indikator keterampilan berpikir kritis yang penting, meliputi: (1) Menyatakan kebenaran pertanyaan atau pernyataan; (2) Menganalisis pertanyaan atau pernyataan; (3) Berpikir logis; (4) Mengurutkan, misalnya secara temporal, secara logis, secara sebab akibat; (5) Mengklasifikasi, misalnya gagasan objekobjek; (6) Memutuskan, misalnya apakah cukup bukti; (7) Memprediksi (termasuk 
membenarkan prediksi); (8) Berteori; dan (9) Memahami orang lain dan dirinya.

Pengertian berpikir logis juga dikemukakan oleh beberapa pakar lainnya (Albrecht, 1984, Minderovic, 2001, Ioveureyes, 2008, Sonias, 2011, Strydom, 2000, Suryasumantri, 1996). Berpikir logis atau berpikir runtun didefinisikan sebagai: proses mencapai kesimpulan menggunakan penalaran secara konsisten (Albrecht, 1984), berpikir sebab akibat, berpikir menurut pola tertentu atau aturan inferensi logis atau prinsip-prisnsip logika untuk memperoleh kesimpulan (Suryasumantri, 1996, Minderovic, 2001, Sponias, 2011), dan berpikir yang meliputi induksi, deduksi, analisis, dan sintesis. Menurut Sumarmo(2005, 168-169) dijelaskan beberapa indikator berpikir logis matematik yaitu: (1) Menarik kesimpulan logis; (2) Memberikan penjelasan dengan menggunakan model, fakta, sifat-sifat,dan hubungan; (3) Memperkirakan jawaban dan proses solusi;(4) Menggunakan pola dan hubungan untuk menganalisis situasi matematika;(5) Menyusun dan menguji konjektur; (6) Merumuskan lawan contoh (counter examples); (7) Mengikuti aturan inferensi, memeriksa validitas argument; (8) Menyusun argumen yang valid; dan (9) Menyusun pembuktian langsung, tak langsung dan menggunakan induksi matematika.

Mengukur sejauh mana siswa mampu menggunakan kemampuan berpikir kritis dan logis yaitu dengan melakukan data hasil tes kemampuan berpikir kritis dan berpikir logis matematik. Aspek yang diukur yaitu pada variabel berpikir kritis dan berpikir logis, indikator variabel yang diukur terdiri dari analogi, generalisasi, kondisional dan silogisma, sedangkan pada variabel pembuktian aspek yang diukur adalah kemampuan siswa menunjukkan, mengembangkan dan penguasaan terhadap materi/soal.

Uraian di atas menunjukkan bahwa kemampuan berpikir kritis dan berpikir logis matematik siswa terkait satu sama lainnya yang perlu di tanamkan sejak dini pada siswa. Namun kemampuan ini sering terabaikan dalam pembelajaran matematika. Pembelajaran matematika masih menganut paradigma lama (transfer of knowledge) yaitu belajar yang kurang mengaktifkan siswa. Pembelajaran yang menganut paradigma tersebut tidak memberikan keleluasan kepada siswa untuk memberdayakan potensi otaknya, karena pembelajaran semacam itu lebih menekankan pada penggunaan fungsi otak kiri. Sementara itu, mengajarkan kemampuan berpkir kritis dan berpikir logis perlu didukung oleh pergerakan otak kanan, misalnya dengan melibatkan unsur-unsur yang dapat mempengaruhi emosi seperti unsur estitika, serta melalui proses belajar yang menyenangkan dan mengasyikkan sehingga pembelajaran menjadi lebih efektif dan siswa menjadi lebih termotivasi untuk belajar matematika.

Upaya memvisualisasikan ide-ide matematika agar matematika bisa benarbenar dipahami oleh siswa, khususnya pada materi eksponen dibutuhkan suatu strategi pembelajaran yang lebih inovatif. Pada penelitian ini peneliti menggunakan model pembelajaran STAD. Sintaks model pembelajaran STAD dalam Chotimah (2007) antara lain: (1) Guru membentuk kelompok yang anggotanya 4 orang secara heterogen; (2) Guru menyajikan pelajaran Guru memberi tugas pada kelompok untuk dikerjakan oleh anggota-anggota kelompok; (3) Peserta didik yang bisa mengerjakan tugas/soal menjelaskan kepada anggota kelompok lainnya sehingga semua anggota dalam kelompok itu mengerti; (4) Guru memberi kuis/pertanyaan kepada seluruh peserta didik. Pada saat menjawab kuis/pertanyaan peserta didik tidak boleh saling membantu; (5) Guru memberi penghargaan (rewards) kepada kelompok yang memiliki nilai/poin tertinggi; (6) Guru memberikan evaluasi; (7) Penutup.

Salah satu media inovatif yang membantu model pembelajaran tipe STAD yaitu dengan pemanfaatan kemajuan 
Teknologi Informasi dan Komunikasi (TIK). Adanya TIK ini dapat memberikan nuansa baru untuk mendorong proses pembelajaran matematika yang lebih baik.

Glass (Kusama, 2003) menyebutkan bahwa banyak sekali kontribusi nyata yang dapat dipersembahkan komputer bagi kemajuan pendidikan, khususnya pembelajaran matematika. Komputer dapat dimanfaatkan untuk mengatasi perbedaan proses belajar siswa; mengajarkan konsep; melaksanakan perhitungan dan menstimulir belajar bagi siswa. Hal ini memperlihatkan bahwa penerapan pembelajaran matematika melalui media komputer akan lebih menyenangkan dan lebih bermakna bagi siswa. Selain itu, pembelajaran melalui media komputer dapat menciptakan iklim belajar yang efektif untuk mengoptimalkan kemampuan matematika, meskipun setiap siswa memiliki kemampuan yang berbedabeda dalam menangkap suatu materi yang diajarkan.

Fey dan Heid (Kusuma, 2003) menyebutkan bahwa ada banyak software yang telah dibuat secara khusus untuk membantu pembelajaran matematika, diantaranya Maple, Matlab, Winplot, Wingeom, Winstat, Winmat, Octave, dll.Salah satu dynamic mathematics software yang dapat dijadikan media pembelajaran pada pembelajaran matematika khususnya materi eksponen disebut Maple. Pembelajaran dengan Maple dapat membantu siswa menvisualisasikan bentuk eksponen menjadi lebih konkret, sehingga siswa dapat lebih memahami konsep dan mencitrakannya dalam pikiran untuk melatih kemampuan berpikir kritis dan dan berpikir logis.

Maple merupakan paket aplikasi matematika yang dapat digunakan untuk melakukan berbagai perhitungan matematik baik secara eksak (analitik) maupun numeric (Sahid, 2003). Menurut Sahid (2003) mengatakan bahwa Maple bisa berupa penyelesaian berupa gambar, grafik, tabel, notasi dan lainnya disesuaikan dengan materi yang akan diajarkan. Ini tidak lepas dari peran komputer yang bisa membantu dalam menyajikan tentang bagaimana operasi Maple ini pada pelajaran Matematika ataupun lainya.

Dengan kemampuan yang dimiliki, Maple merupakan sebuah alat bantu yang handal untuk pemecahan masalah matematika, baik masalah komputasi numerik, aljabar simbolik, maupun visualisasi.

Program ini sudah digunakan oleh pelajar SMA khususnya di Eropa dan Amerika. Dengan memanfaatkan program ini, kedepan akan muncul pelajar-pelajar Indonesia yang hebat disemua bidang keilmuan karena memang sekarang ini matematika menjadi dasar dari pengembangan semua cabang keilmuan.Selain itu software Maple ini mampu menyelesaikan permasalahanpermasalahan matematika yang rumit. Agar Software Maple ini dapat berfungsi dengan baik, tentu diperlukan model pembelajaran yang dapat mendukung pembelajaran interaktif,yaitu model kooperatif tipe Student TeamsAchievement Division (STAD). Pembelajaran kooperatif tipe STAD terdiri dari empat langkah utama yaitu: presentasi kelas, kerja tim, kuis dan penghargaan kelompok (Chotimah, 2007). Hal itu disebabkan sangat membantu satu sama lain untuk memahami bahan pelajaran, baik itu melalui tutorial, kuis atau melakukan diskusi dan memacu motivasi siswa untuk senantiasa mengikuti kegiatan belajar mengajar dengan serius.

Keterkaitan pembelajaran kooperatif STAD terhadap kemampuan berpikir kritis dan kemampuan berpikir logis matematik siswa pada saat diberikan materi eksponen dan lembar kerja siswa melalui pembelajaran matematika dengan berbantuan Maple dapat meningkatkan kemampuan matematik siswa. Hal tersebut dapat dipahami dari salah satu langkah STAD yaitu kerja kelompok, dengan adanya kerja kelompok pada STAD ini membuat siswa aktif dan terlibat langsung dalam pembelajaran matematika. Aktif dan keterlibatan siswa dalam proses pembelajaran menjadikan kemampuan 
matematik siswa dapat berkembang termasuk kemampuan berpikir kritis dan kemampuan berpikir logis.

Terdapat beberapa penelitian terdahulu yang pernah dilakukan dengan model pembelajaran kooperatif STAD berbantuan Maple. Salah satunya adalah penelitian Achmad (2007) menunjukkan Keefektivan Penggunaan Autograph Cabri 3D dan Maple Sebagai Media Pembelajaran Matematika. Sedangkan dalam penelitian Kariasa (2014) diperoleh kesimpulan bahwa kemampuan berpikir kritis matematik antara siswa yang pembelajarannya menggunakan model kooperatif tipe STAD lebih baik dengan siswa yang pembelajarannya menggunakan pembelajaran konvensional ditinjau dari penalaran formal.

Dari penelitian di atas, peneliti ingin mengetahui apakah peningkatan kemampuan berpikir kritis matematik siswa yang mendapat pembelajaran matematika melalui model kooperatif tipe STAD berbantuan Maple lebih baik daripada siswa yang mendapat pendekatan konvensional, ditinjau dari: (a) keseluruhan siswa dan (b) subkelompok siswa (tinggi, sedang, rendah). Khususnya dalam penelitian ini peneliti bertujuan Untuk mengetahui peningkatan kemampuan berpikir logis matematik siswa yang mendapat pembelajaran matematika melalui model kooperatif tipe STAD berbantuan Maple lebih baik daripada siswa yang mendapat pembelajaran konvensional, ditinjau dari: (a) keseluruhan siswa dan(b) subkelompok siswa (tinggi, sedang, rendah).

\section{METODE}

Penelitian ini menggunakan metode eksperimen dengan pendekatan kuantitatif. Terdapat dua kelompok sampel pada penelitian ini yaitu kelompok eksperimen melakukan pembelajaran matematika melalui model pembelajaran kooperatif tipe STAD berbantuan Maple dan kelompok kontrol melakukan pembelajaran dengan konvensional. Kedua kelompok diberikan pre-test dan post-test, dengan menggunakan instrumen tes yang setara. Sugiyono (2013: 107) menyatakan bahwa penelitian eksperimen adalah suatu penelitian yang berusaha mencari pengaruh variabel tertentu terhadap variabel lain dalam kondisi yang terkontrol secara ketat. Desain yang digunakan dalam penelitian ini adalah desain "Pretest-Posttest Control Grup Desain" (Sugiyono, 2013: 112) dengan rancangan seperti pada Tabel 1 berikut:

Tabel 1 Desain Penelitian

\begin{tabular}{cccc}
\hline Kelompok & Pretest & Perlakuan & Posttest \\
\hline Eksperimen & $\mathrm{O}$ & $\mathrm{X}$ & $\mathrm{O}$ \\
\hline Kontrol & $\mathrm{O}$ & & $\mathrm{O}$ \\
\hline
\end{tabular}

Keterangan O :Pretest dan Posttest

$\mathrm{X}$ : Pembelajaran matematika dengan model kooperatif tipe STAD berbantuan Maple.

Instrumen tes yang digunakan untuk mengukur kemampuan berpikir kritis dan logis matematik dalam penelitian ini berupa seperangkat soal yang berbentuk uraian. Pemberian soal uraian dimaksudkan untuk melihat proses kemampuan siswa, ketelitian dan sistematika penyusunan jawaban yang dapat dilihat dari langkah-langkah penyelesain soal yang dibuat. Tes pretest dilakukan pada awal sebelum proses pembelajaran dan tes postest dilakukan pada akhir proses pembelajaran. Tes pretest diberikan untuk melihat kesetaraan kemampuan awal kedua kelas sedangkan tes postest diberikan untuk mengetahui ada tidaknya peningkatan kemampuan berpikir kritis dan logis matematik siswa setelah dilakukan pembelajaran dengan model pembelajaran kooperatif tipe STAD berbantuan maple. Langkah awal yang dilakukan peneliti dalam menyusun tes adalah membuat kisi-kisi soal kemudian baru dilanjutkan menyusun soal dan kunci jawaban serta menentukan skor untuk setiap butir soal.Sebelum digunakan, instrumen tes terlebih dahulu divalidasi untuk mengetahui validitas isi dan validitas muka. Validitas isi didasarkan pada (1) kesesuaian antara indikator dengan butir soal, (2) kelayakan 
butir soal untuk siswa kelas X SMK Negeri 1 Sigli, dan (3) kebenaran materi yang diujikan, sedangkan untuk mengukur validitas muka, didasarkan pada kejelasan soal dari segi bahasa, sajian, dan akurasi gambar. Data yang diperoleh dalam penelitian ini yaitu data kuantitatif. Data kuantitatif diperoleh dari hasil tes kemampuan berpikir kritis dan kemampuan berpikir logis matematik, data ini diolah dengan dengan langkah-langkah Menguji normalitas data skor pretest dan gain dengan menggunakan uji statistik One Sample Kolmogorov-smirnov (Uyanto, 2009), Menguji homogenitas varians skor pretest dan gain untuk melihat homogenitas atau kesamaan beberapa bagian sample yaitu seragam tidaknya varians sampel-sampel yang diambil dari populasi yang sama, Untuk menentukan perbedaan antara kelompok eksperimen dan kelompok kontrol digunakan uji perbedaan dua rata-rata menggunakan uji-t, Untuk mengetahui peningkatan kemampuan berpikir kritis dan logis matematik dalam penelitian ini dapat dilakukan dengan menggunakan rumus gain ternormalisasi, untuk menentukan perbedaan peningkatan kemampuan berpikir kritis dan logis matematik antara subkelompok rendah, subkelompok sedang, dan subkelompok tinggi dari dua kelompok kelas eksperimen dan kelas kontrol, menggunakan uji perbedaan rerata tiga buah subkelompok dengan analisis varians dua jalur (Anova dua-jalur) apabila datanya berdistribusi normal dan homogen.

\section{HASIL DAN PEMBAHASAN}

Penelitian ini bertujuan untuk mengetahui perbedaan peningkatan kemampuan berpikir kritis dan logis matematik antara siswa yang memperoleh pembelajaran dengan model kooperatif tipe STAD berbantuan Maple dan siswa yang memperoleh pembelajaran konvensional baik ditinjau secara keseluruhan maupun berdasarkan subkelompok siswa. Penelitian ini melibatkan 60 siswa yang dijadikan sebagai sampel penelitian. 60 siswa yang dianalisis datanya yaitu 30 siswa kelas eksperimen dan 30 siswa kontrol.

Tabel 2 Hasil Uji Perbedaan Rata-rata NGain Kemampuan Berpikir Kritis Matematik

\begin{tabular}{ccccc}
\hline Kelas & $\begin{array}{c}\text { t } \\
\text { hitung }\end{array}$ & $\begin{array}{c}\text { Sig. } \\
(\mathbf{2 -} \\
\text { tailed) }\end{array}$ & $\begin{array}{c}\text { Sig. } \\
(\mathbf{1 -} \\
\text { tailed) }\end{array}$ & Kesimpulan \\
\cline { 1 - 1 } Eksperimen & 1,996 & 0,051 & 0,0225 & Tolak $\mathrm{H}_{0}$ \\
\cline { 1 - 1 } Kontrol & & & & \\
\hline
\end{tabular}

Dari tabel 2 di atas dapat dilihat bahwa pada N-Gain kemampuan berpikir kritis matematik dengan nilai $t=1,996$ dan Sig. (2tailed) $=0,051$. Karena melakukan uji hipotesis satu sisi (1-tailed) maka nilai sig. (2-tailed) harus dibagi dua menjadi nilai Sig. $(1$-tailed $)=0,0225$. Karena nilai Sig. $(1-$ tailed $)<$ taraf Signifikansi $(\alpha=0,05)$, maka $H_{o}$ ditolak. Sehingga dapat disimpulkan bahwa rata-rata gain ternormalisasi kemampuan berpikir kritismatematik kelas eksperimen lebih baik daripada rata-rata gain ternormalisasi kelas kontrol.

Tabel 3 Hasil Uji Perbedaan Rata-rata NGain kemampuan Berpikir Logis Matematik

\begin{tabular}{ccccc}
\hline Kelas & $\begin{array}{c}\mathrm{t} \\
\text { hitung }\end{array}$ & $\begin{array}{c}\text { Sig. } \\
(2- \\
\text { tailed })\end{array}$ & $\begin{array}{c}\text { Sig. (1- } \\
\text { tailed })\end{array}$ & Kesimpulan \\
\cline { 1 - 1 } Eksperimen & & & & \\
\cline { 1 - 1 } Kontrol & 2,211 & 0,031 & 0,0155 & Tolak $\mathrm{H}_{0}$
\end{tabular}

Dari tabel 3 di atas dapat dilihat bahwa pada $\mathrm{N}$-Gain kemampuan berpikir logis matematik dengan nilai $t=2,211$ dan Sig. (2tailed) $=0,031$. Karena melakukan uji hipotesis satu sisi (1-tailed) maka nilai sig. (2-tailed) harus dibagi dua menjadi nilai Sig. $(1$-tailed $)=0,0155$. Karena nilai Sig. (1tailed $)<$ taraf Signifikansi $(\alpha=0,05)$, maka $H_{o}$ ditolak. Sehingga dapat disimpulkan bahwa rata-rata gain ternormalisasi kemampuan berpikir Logis matematik kelas eksperimen lebih baik daripada rata-rata gain ternormalisasi kelas kontrol. 
Tabel 4 Analisis Varian Data N-Gain Kemampuan Berpikir Kritis Matematik

\begin{tabular}{lrrrrr}
\hline \multirow{1}{*}{ Source } & $\begin{array}{l}\text { Type III } \\
\text { Sum of } \\
\text { Squares }\end{array}$ & Df & $\begin{array}{c}\text { Mean } \\
\text { Square }\end{array}$ & F & Sig. \\
\hline Pembelajaran & .121 & 1 & .121 & 42,372 & .000 \\
\hline Subkelompok & 4,373 & 2 & 2,187 & 767,375 & .000 \\
\hline $\begin{array}{l}\text { pembelajaran } * \\
\text { subkelompok }\end{array}$ & .021 & 2 & .011 & 3,694 & .031 \\
\hline Error & .154 & 54 & .003 & & \\
\hline Total & 18,889 & 60 & & & \\
\hline Corrected Total & 4,930 & 59 & & & \\
\hline
\end{tabular}

Berdasarkan hasil perhitungan anova dua jalur yang terdapat pada tabel 4 dapat disimpulkan bahwa subkelompok siswa memberikan pengaruh yang signfikan terhadap peningkatan kemampuan berpikir kritis matematiksiswa. Hal ini terlihat dari nilai sig. yang diperoleh untuk pembelajaran yaitu 0,00 dan nilai ini lebih kecil dari taraf signifikansi yang telah ditetapkan yaitu 0,05 sehingga berdasarkan kriteria pengujian maka $\mathrm{H}_{0}$ ditolak atau dengan kata lain $\mathrm{H}_{\mathrm{a}}$ diterima.

Tabel 5 Analisis Varian Data N-Gain

Kemampuan Berpikir Logis Matematik

\begin{tabular}{lrrrrr}
\hline \multicolumn{1}{c}{ Source } & $\begin{array}{l}\text { Type III } \\
\text { Sum of } \\
\text { Squares }\end{array}$ & Df & $\begin{array}{c}\text { Mean } \\
\text { Square }\end{array}$ & F & Sig. \\
\hline Pembelajaran & .126 & 1 & .126 & 38,975 & .000 \\
\hline Subkelompok & 3,102 & 2 & 1,551 & 478,768 & .000 \\
\hline $\begin{array}{l}\text { pembelajaran * } \\
\text { subkelompok }\end{array}$ & .025 & 2 & .013 & 3,920 & .026 \\
\hline Error & .175 & 54 & .003 & & \\
\hline Total & 20,934 & 60 & & & \\
\hline Corrected Total & 3,621 & 59 & & & \\
\hline
\end{tabular}

Berdasarkan hasil perhitungan anava dua jalur yang terdapat pada tabel diatas dapat disimpulkan bahwa subkelompok siswa memberikan pengaruh yang signfikan terhadap peningkatan kemampuan berpikir logis matematik siswa. Hal ini terlihat dari nilai sig. yang diperoleh untuk pembelajaran yaitu 0,00 dan nilai ini lebih kecil dari taraf signifikansi yang telah ditetapkan yaitu 0,05 sehingga berdasarkan kriteria pengujian maka $\mathrm{H} 0$ ditolak atau dengan kata lain $\mathrm{Ha}$ diterima.

Berdasarkan beberapa tabel diatas dapat disimpulkan bahwa peningkatan kemampuan berpikir kritis dan logis matematik siswa yang mendapatkan pembelajaran dengan model kooperatif tipe STAD berbantuan Maple secara signifikansi lebih baik daripada siswa yang mendapatkan pendekatan konvensional bila ditinjau secara keseluruhan dan subkelompok siswa (tinggi, sedang,rendah).

\section{Simpulan}

Berdasarkan hasil penelitian dan pembahasan yang telah dikemukakan pada bagian terdahulu dapat diambil beberapa simpulan yang berkaitan dengan peningkatan kemampuan berpikir kritis dan logis matematik siswa SMK Negeri 1 Sigli melalui model pembelajaran kooperatif tipe STAD berbantuan Maple. Adapun kesimpulan tersebut sebagai berikut:

1. Peningkatan kemampuan berpikir kritis matematik siswa yang mendapat pembelajaran matematika melalui model kooperatif tipe STAD berbantuan Maple lebih baik daripada siswa yang mendapat pendekatan konvensional ditinjau dari keseluruhan dan subkelompok siswa (tinggi, sedang, rendah).

2. Peningkatan kemampuan berpikir logis matematik siswa yang mendapat pembelajaran matematika melalui model kooperatif tipe STAD berbantuan Maple lebih baik daripada siswa yang mendapat pendekatan konvensional ditinjau dari keseluruhan dan subkelompok siswa (tinggi, sedang, rendah).

\section{DAFTRA PUSTAKA}

Achmad. (2007). Keefektifan Penggunaan Autograph, Cabri 3D dan Maple sebagai Media Pembelajaran Matematika (e-journal Pendidikan Matematika IKIP PGRI Semarang, Volume 1 No. 1 tahun 2007). 
Agustine, (2009). Pengaruh Penggunaan Strategi Heuristik terhadap Peningkatan Kemampuan Berpikir Kritis Matematika Siswa. Skripsi Jurusan Pendidikan Matematika FKIP UNPAS: tidak diterbitkan.

Albrecht, (1984). Mathematic for Elementary Teachers A Conceptual Approach, WI New York: Aleks Corporation.

Anderson (2003). Critical Thinking Across the Disciplines. Makalah pada Faculty Development Seminar in New York City College of Technology, New York.

(Kariasa. (2014). Pengaruh Model Pembelajaran Kooperatif Tipe STAD dengan Pendekatan Pemecahan Masalah Terhadap Kemampuan Berpikir Kritis Matematis ditinjau dari penalaran Formal. (e-Jurnal Program Pascasarjana Universitas Pendidikan Ganesha Program Studi Matematika, Volume 3 tahun 2014).

Kusuma. (2003). Konsep Pengembangan dan Implementasi Computer-Based Learning dalam Peningkatan Kemampuan High-Order Thiking. UPI Bandung: Tidak diterbitkan.
Ruseffendi, E.T. (2000). Pengantar Kepada Membantu Guru Mengembangkan Kompetensinya Dalam Pengajaran Matematika untuk Meningkatkan CBSA. Bandung: Tarsito.

Sahid, MSc. (2003). Penggunaan MAPLE untuk pembelajaran Aljabar. Universitas Negeri Yogyakarta: Journal "Lab Komputer Jurdik Matematika FMIPA UNY

Setiawan. (2011). Meningkatkan Kemampuan Koneksi dan Pemecahan Masalah Matematik Siswa melalui Pembelajaran Kooperatif Model Cooperative Integreted Reading and Composition (CIRC). Tesis SPS UPI. Bandung: Tidak diterbitkan.

Sumarmo, (1987). Berpikir dan Disposisi Matematis serta Budi Pekerti dalam Pembelajaran Matematika. Hand-out seminar Pendidikan Matematika. Yogyakarta: tidak diterbitkan.

Sumarno. (2002). Alternatif Pembelajaran Matematika dalam Menerapkan Kurikulum Berbasis Kompetensi. Makalah pada Seminar Tingkat Nasional FPMIPA UPI. Bandung: tidak diterbitkan. 